\title{
Small firms and patenting revisited
}

\author{
Suma S. Athreye $\mathbb{D}$ - Claudio Fassio • Stephen Roper
}

Accepted: 20 January 2020 / Published online: 6 February 2020

(C) The Author(s) 2020

\begin{abstract}
In order to observe a patent application at the firm level, two conditions need to be met: new products need to be of patentable quality, which depends both on the degree of novelty of innovations and on the total number (portfolio) of innovations; and the benefits of patents need to be higher than the costs of owning them. Analyzing the patent propensity of small and large UK firms using a novel innovation-level survey (the SIPU survey) linked to Community Innovation Survey data, we find that when we consider the whole innovation portfolio, smaller firms do patent less than larger firms. However, using data on individual innovations, we find that smaller firms are no less likely to patent any specific innovation than larger firms. We argue that size differences in the probability to patent relate primarily to the "portfolio effect," i.e., larger firms generate more innovations than smaller firms, and therefore are more likely to create one or more which are patentable. As for the decision to patent a patentable innovation, we find that cost barriers, more than issues of innovation quality or
\end{abstract}

S. S. Athreye $(\bowtie)$

Essex Business School, University of Essex, Southend on Sea, Essex SS1 1LW, UK

e-mail: suma.athreye@essex.ac.uk

C. Fassio

Department of Business Administration, Centre for Innovation Research and Competence in the Learning Economy (CIRCLE), Lund University, Lund, Sweden

\section{S. Roper}

Enterprise Research Centre (ERC), Warwick Business School, University of Warwick, Coventry, England, UK enforceability, deter small firms from patenting specific innovations. Measures to address the costs of patenting for smaller - perhaps by considering patents as eligible costs for R\&D tax credits - and/or subsidizing SMEs' participation in IP litigation schemes may both encourage patent use by smaller firms.

Keywords Patenting $\cdot \mathrm{SME} \cdot$ Small firms $\cdot$ UK

JEL classifications $\mathrm{O} 32 \cdot \mathrm{O} 34 \cdot \mathrm{O} 38 \cdot \mathrm{L} 26$

\section{Introduction}

Innovation - the market introduction of new products, services or processes - can add value for producers and consumers and drive economic growth (Baumol, 2002). Innovating firms may gain a first mover advantage, earn higher returns, and establish a position of market leadership (Ulhoi, 2012). Among innovators, small firms have an almost mythical role as the source of new and radical ideas and the motors of creative destruction (Schumpeter, 1912). However, it is widely recognized that firms of all sizes find it difficult to appropriate the returns to innovation leading to under-investment in R\&D and innovation. One element of the policy response to this problem has been the development of legal forms of intellectual property (IP) protection such as patents and trademarks. In each case, the main objective is to limit imitation and help innovating firms appropriate the returns to their investment. 
An enduring debate in discussions of IP policy, however, has been the questionable value of patenting for small firms (Fernandez-Ribas, 2010; Veer \& Jell, 2012; Marzi, Dabic, Daim, \& Garces, 2017). There are several separate strands of argument that contribute to this belief. The work of Cohen, Nelson, and Walsh (2000) suggested that small firms are a distinct group and prefer to protect their intellectual property using non-patent methods. Why should this be the case? Two types of explanations dominate the literature. The first argues that small firms may simply be less familiar with formal IP mechanisms. As Hall, Helmers, Rogers, and Sena (2013) note in their analysis of UK firms "Because firms that use one IP mechanism are more likely to use another, another possibility is that firms have a "propensity" to use or not use IP, and that the problem is lack of familiarity with the system and sub-optimal behavior on the part of some firms". The second explanation in the research literature and public policy documents is that due to resource constraints and/or registration and defense costs, patenting is of little value, as an intellectual property (IP) protection mechanism for small firms (Hughes \& Mina, 2010; Athreye \& Fassio, 2018).

Ensuring that IP policy "works" for both larger and smaller firms is important to maximize the social value of innovation. Here, we revisit the reasons for small firms' low patenting rates and make three contributions to our understanding. First, we develop a conceptual framework which looks more carefully at why small firm may or may not use patents. In particular, we distinguish between the probability of having a patentable innovation and the decision to apply for it based on a cost-benefit analysis. Further, we distinguish between two factors that may cause a firm to have smaller or larger numbers of patentable innovations, viz. firms' propensity to patent any specific innovation and the breadth of firms' portfolio of patentable innovations.

Second, we show that there are no theoretical arguments which unequivocally suggest that small firms should have a lower propensity to patent any specific innovation, although resource constraints suggest that smaller firms are likely to have a smaller portfolio of patentable innovations. Further, we argue that having a portfolio which includes patentable innovations is only a necessary condition for whether or not a firm will actually make a patent application. This decision also depends on the perceived benefit-cost ratio of patenting being positive - the sufficient condition for patenting by small firms.
Third, we test our hypotheses using a novel database that combines innovation-level information that can be linked to the UK Community Innovation Survey 2015. By linking the two databases, we obtain information on the extent to which firms use patents and, where applicable, their reasons for not patenting. These data help us to see that most existing analyses of patenting by small firms confound the portfolio and propensity to patent effects. Looking more closely at the reasons for not patenting, we conclude that small firms are deterred by the costs of patenting rather than any other concerns, including lack of awareness.

Our results have important implications for patent policy, especially in the UK, from where our data are drawn. IPO (2017) notes that the UK was the sixth largest national jurisdiction in terms of number of patent applications filed, in a world ranking led by China and the USA, in 2014. Adjusting these figures for GDP and population puts the UK fourth and second in the world respectively. However, the vast majority of UK patent applications are filed by foreign applicants. In 2012, only $7 \%$ of patent applications covering the UK (including patents valid in the EPO) were filed by domestic applicants, compared to $34 \%$ in Germany, $48 \%$ in the USA, and $76 \%$ in South Korea. ${ }^{1}$ The reason for this is believed to be the increasing dominance of service industries even in hitherto manufacturing sectors, and the dominance of Knowledge Intensive Business Services (less protected by patents) in innovative activities.

In an overall climate of low patenting, where even large UK firms accounted for only small shares of patenting, the statistics on patenting from SME firms in the UK is even more worrying. IPO (2017: p.37) notes that based on different definitions of size (assets, turnover, and employment) between 0.6 and $1.5 \%$ of SMEs and less than $1 \%$ of micro enterprises had patents published in 2014. This compared to about $4 \%$ of large firms that patented in 2014. As patenting has been shown to have large follow-on effects for innovation in small firms (Galasso \&

\footnotetext{
${ }^{1}$ Using an alternative measure more tied to innovation activity viz. measuring patents per million Euros of $R \& D$ solely within the manufacturing sector does control to some extent for differences in sector and levels of R\&D investment. Even by this measure, UK companies still have lower patents, with 0.5 patents per million Euros of R\&D compared to one patent per million Euros of R\&D in Germany, France, the USA, and China, 3.7 in Japan and 6.1 in Korea. As this is a sample of large $\mathrm{R} \& \mathrm{D}$ investing companies, and differences in the UK economy as a whole could be even larger. (IPO 2017: p.50)
} 
Schankerman, 2015), finding ways to reduce the barriers for small firms may have a large impact on the growth of innovative small firms.

IP offices have hitherto operated outreach programs to raise awareness of IP instruments among smaller firms based on the implicit belief that small firms have a lower propensity to patent their innovations. ${ }^{2}$ The arguments in this paper about the salience of cost barriers suggest that IP policy may also need to develop measures which can reduce patenting costs for small firms. These could take several forms but the most important is likely to be helping with the legal costs of patent enforcement.

The remainder of the paper is organized as follows. In Section 2, we outline our conceptual framework which differentiates between firms' ability to develop patentable innovations, a necessary condition for patenting, and the cost-benefit of actually patenting, the sufficient condition. Section 3 profiles our data and empirical approach and Section 4 describes the main results. Section 5 summarizes the key points and draws out the implications.

\section{Conceptual framework}

Previous studies have suggested that the conditions for patenting may work differently in larger and smaller firms. In terms of the ability to generate patentable innovations, the flexibility and responsiveness of small firms may offset their limited resource compared to larger firms (Vossen, 1998). However, we might generally anticipate that larger firms have more significant portfolios of innovations. In terms of the benefit-cost ratio which may influence the propensity to patent any specific innovation, this is generally argued to favor larger companies (Hughes \& Mina, 2010). Patents may be expensive to implement, disproportionately so perhaps for small firms, and may be overly costly for small firms to defend effectively (Perez-Cano \& Villen-Altamirano, 2013). We discuss each in turn.

\footnotetext{
${ }^{2}$ IPO initiatives such as IP Equip, the IP Health Check and the IP finance toolkit help companies, particularly SMEs, towards a better understanding of how patenting their innovations can enhance their business.
}

\subsection{Developing patentable innovations}

Firms' decisions about whether to invest in innovation, and which innovation projects to undertake, will reflect cognitive, behavioral, and organizational resource factors. Among the cognitive influences, having a smaller senior management team within small firms will inevitably limit their cultural and experiential diversity, with potentially negative impacts on creativity and market understanding (Galia \& Zenou, 2012; Talke, Salomo, \& Rost, 2010). This may reduce small firms' ability both to perceive market opportunities and develop innovative responses. Small firms more limited management teams may also mean they have weaker search capabilities, absorptive capacity, and specialist understanding than that available in larger businesses. This may limit small firms' ability to take advantage of external knowledge or form (or effectively exploit) external innovation partnerships (Valentim, Lisboa, \& Franco, 2016; Vahter, Love, $\&$ Roper, 2014). Both the limited diversity and cognitive capabilities of the managerial teams of small firms seem likely to limit both the extent and degree of novelty of small firms' innovation portfolios. ${ }^{3}$

Behavioral factors linked to firms' performance objectives; managerial practices or routines may also be important in shaping firms' innovation portfolios. Where firms have ambitious performance targets, this may lead to innovation portfolios which are larger and more radical (Gundry, Kickul, Welsch, \& Posig, 2003) with the potential for first-mover advantage (Kopel \& Loffler, 2008). Firms with more modest performance goals may instead place more emphasis on incremental innovation (Kok \& Ligthart, 2014). Management practices may also have an impact on innovation, with transformational leadership practices more strongly associated with radical innovation (Rosing, Frese, \& Bausch, 2011). Firms' engagement with design leadership (Design Council, 2015), advanced management techniques (Bourke \& Roper, 2016), and quality improvement (Bourke \& Roper, 2017) may also positively influence innovation outcomes. It is not clear a priori whether these behavioral effects on the probability of developing patentable innovations will be more felicitous in smaller or larger firms: smaller - and particularly younger firms - may have more ambitious performance

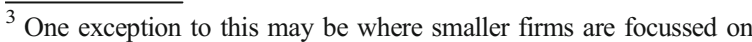
super-niche market strategies or specific technologies such as in the German Mittelstand (Venohr \& Mayer, 2007; Simon, 1996).
} 
goals and more dynamic leadership, while more established firms may have advantages in terms of engagement with design and leading-edge management practices.

In organizational terms, small firms' advantages in terms of flexibility have been contrasted with resource limitations which may reduce their ability to develop innovations of sufficient novelty to be patentable (Vossen 154998). R\&D activity in smaller firms, for example, may be informal and ad hoc, reducing both knowledge creation and absorption capacity (Griffith, Redding, \& Van Reenan, 2003). Smaller firms' knowledge search and boundary spanning capabilities may also be more limited (Mina, Bascavusoglu-Moreau, \& Hughes, 2014). However, hierarchic and functional structures within larger firms may inhibit knowledge flows and diffusion across the organization reducing levels of innovation (Leonard-Barton, 1992). A priori, as with the behavioral influences considered earlier, organizational factors may therefore have an uncertain effect on the probability that small and larger firms will successfully generate patentable innovations.

\subsection{The benefit-cost ratio of patenting}

The costs of establishing a patent are significant and impact disproportionately on small firms (Kingston, 2001). Beyond the financial implications, there may also be strategic costs or risks associated with patenting and disclosure - patents are public documents which provide detailed information on an invention. "It is often the case that imitation is still possible without infringing an incumbent innovator's rights: the nature of the technology might make it possible to 'invent around' a particular design or technical specification" (Hughes \& Mina, 2010, p. 9).

The central benefit provided by a patent is temporary monopoly, but the economic value of this depends on firms' ability to appropriate the benefits of that monopoly. Both commercial and legal aspects are important in determining the firms' ability to appropriate the value of a patent. Small firms may be in a weaker position than larger firms to directly appropriate the benefits of patents, however, Hughes and Mina (2010, p. 9) summarize evidence from Giuri et al. (2007) and Gambardella, Giuri, and Luzzi (2007) which suggests that across Europe: "small firms exploit internally $55.8 \%$ of their patents. ... Smaller firms also have a relatively high percentage of patents that are licensed out $(15.0 \%)$... smaller firms report very low figures for unused patents. Taken together, these results are consistent with smaller firms licensing out more in pursuit of the complementary assets necessary to develop and appropriate value. They are also consistent with an inability or reluctance to maintain sleeping or dormant patents because of the relatively high fixed costs which many small firms may be unwilling or unable to bear. They thus may patent more viable intellectual property".

Whether firms directly exploit or license patented technology, they may also need to enforce patents if infringed. Hughes and Mina (2010, p. 2) suggest that "even where SMEs are able to recognize the importance of patenting and to put in place appropriate patents, they may be at a substantial disadvantage in enforcing their IP rights. This is particularly likely to be the case with respect to larger firms who not only may have a sufficiently deep pocket to protect their own IP or challenge the IP of SMEs, but may have greater competence at both designing and defending their own patent position against emergent rival patents". Qualitative interviews reported in IPO (2017) suggest that small firms also perceive the high costs of potential litigation as part of the overall cost of patenting.

Patents may also generate value for a business through signaling to "partners and external finance, in producing an increase in the company's market value, in helping capture new market share or protect the existing one, and in serving as an asset base capable of reinforcing the company's competitive advantage by way of access to external technologies." (Perez-Cano \& VillenAltamirano 2013, p. 27). Signaling advantages depend strongly on sector with US studies highlighting a strong concentration of patents in a few industries, namely pharmaceutical, biotechnology, medical equipment, chemicals, computers, and special purpose machinery.

\subsection{Hypothesis development ${ }^{4}$}

These management and resource differences between small and larger firms result in quite different profiles of innovation activity and patenting behavior. For example, it is widely accepted in the empirical literature on patents that large firms have a higher propensity to patent than small firms. Small firms are usually expected to prefer other informal IP protection

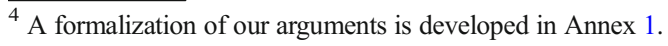


mechanisms, such as secrecy, rather than the more formal, costly, and bureaucratic patents. Using survey data for several European countries, Arundel (2001) finds that the propensity to use secrecy rather than formal patent protection is higher among small firms than among large firms. Pajak (2016) also finds that even among small firms with less than 30 employees size is negatively associated with patent applications. Hall et al. (2013) using a sample drawn from the Community Innovation Survey (CIS), focused on UK firms, find again that firm size, as proxied by number of employees, is negatively related to the preference for protection by patents versus secrecy. Many of the prior studies that have analyzed the patenting probability of firms also point to the role of $R \& D$ and other resources that may be associated with firm size in explaining patenting behavior (Levin et al. 1987; Arundel \& Kabla, 1998; Arora et al. 2008). Thus, the overall resource advantage enjoyed by larger firms in conducting R\&D also suggests that they will have a larger portfolio of innovations which will be patented. The combination of resource and portfolio effects suggests our first hypothesis:

\subsubsection{Hypothesis 1: Firm-level propensity to patent}

\section{Large firms have a higher overall propensity to patent} when compared to small firms

The typical distribution of the value of innovations, even within a single firm's portfolio, is usually strongly asymmetric, with few innovations often accounting for a very large share of all sales (Scherer \& Harhoff, 2000). This may suggest that firms implement very different strategies for different innovations, according to their specific value or perceived value. Moreover, as stressed by Arora, Athreye, and Huang (2013), the propensity to patent of small firms may reflect the small number of patentable innovations created by smaller firms. In other words, given a similar propensity to patent between firm A (large firm) and firm B (a small firm), the likelihood of patenting will be lower for firm B simply because it introduces fewer patentable innovations, than firm A.

Generally, it is not easy to identify the separate effects of the propensity to patent and firms' innovation portfolio as most survey datasets on innovation measure outcomes at the firm level rather than for any given innovation. A sensible empirical strategy needs to get rid of the effect of the portfolio effect from the number of inventions, so that patenting behavior can be observed as a function of patentability alone. Thus, our second conjecture is as follows:

\subsubsection{Hypothesis 2: Innovation-level propensity to patent}

Comparing like for like, for any innovation of value, the propensity to patent between large and small firms is not different.

Lastly, and following the discussion in Section 2.2, patentability is only a necessary condition for patenting. If an invention is patentable, firms will decide on patenting based on the perceived costs and benefits which may include the nature of competition faced by the firm and the costs of patenting. Put differently, while patentability gives us the necessary condition for patenting, the sufficient condition for patenting is a function of perceived costs and benefits. This suggests our third hypothesis:

\subsubsection{Hypothesis 3: Size differences in the costs and benefits of patenting}

Small firms face greater barriers to innovation on account of the costs of creating and defending patents than larger firms.

\section{Data and empirical methods}

\subsection{Data sources}

The UK Intellectual Property Office (IPO) commissioned the Survey of Innovation and Patent Use (SIPU) to identify the main barriers to the use of intellectual property protection in the UK. SIPU 2015 focussed on understanding the characteristics of firms' "most valuable innovation." It asked whether these innovations were protected by patents and trademarks and, if they were not the reasons why firms had not applied for patent or trademark protection.

SIPU 2015 sampled all firms who had agreed to respond to questions about their most valuable innovation from the 15,091 firms that were surveyed by UK Innovation Survey (UKIS) 2015. This provided a total eligible sample of 886 businesses. Four hundred seventy-seven (54\%) of these businesses had specifically indicated on the UKIS 2015 that they had engaged in innovation in product, process, or business strategy in 
Table 1 Comparison of SIPU and UKIS 2015 respondents

\begin{tabular}{lrr}
\hline & UKIS & \multicolumn{1}{c}{ SIPU } \\
& $N=15,091$ & $N=634$ \\
\hline A. By firm sizeband & & \\
Small (10-49 employees) & 44 & 55 \\
Medium (50-249 employees) & 36 & 30 \\
Large (250 plus employees) & 20 & 15 \\
Total & 100 & 100 \\
B. By innovation type & & \\
Product or service & 14 & 27 \\
Process & 16 & 8 \\
Product/service and/or process & 24 & 35 \\
C. By sector (SIC 2007) & & \\
Primary (SIC 2007 05-09) & 0.9 & 0.5 \\
Manufacturing (SIC 2007 10-33) & 16.3 & 18.3 \\
Utilities (SIC 2007 35-39) & 1.5 & 1.3 \\
Construction (SIC 2007 41-43) & 4.9 & 3.6 \\
Wholesale and retail services (45-47) & 31.0 & 27.8 \\
Other services (49-83) & 45.4 & 48.6 \\
Total & 100 & 100 \\
\hline Sources:Auth' & & \\
\hline
\end{tabular}

Sources: Authors' computations on SIPU 2015 merged with UKIS 2015

the period 1 January 2012 to 31 December 2014. The survey was administered by the telephone survey team from the Office of National Statistics soon after the conclusion of the UK Innovation Survey 2015. The SIPU survey achieved a response rate of $72 \%$ with responses from 277 innovators and 291 non-innovators. We were also able to look up the CIS responses for each SIPU respondent.

To illustrate the representativeness of the SIPU respondents, we compare it to the UKIS 2015 in three dimensions (Table 1). First, we examine business size. SIPU over-sampled small firms but under-sampled medium and large firms in comparison to the UKIS. This is likely to reduce the proportion of innovating firms in SIPU relative to the UKIS. Second, SIPU over-sampled innovative firms overall, but also over-sampled product innovators vis-à-vis the UKIS (Table 1, part B). Finally, when we compare the industry composition of SIPU with UKIS 2015, and see a broadly similar industrial composition (Table 1, part C). The biases in the SIPU sample make direct comparisons with the aggregates in the UKIS problematic and we account for this in our empirical analysis.

Innovation itself is recorded differently in the two surveys. In a 3-year period, a firm may generate several innovations some of which are more valuable than others. The UKIS asks firms to record their strategy over the totality of innovations introduced from 2012 to 2014. SIPU focuses only on firms' most valuable innovation. As we noted in Section 2, not being able to observe how many innovations a firm produces makes it difficult to disentangle the portfolio and propensity to patent effects. To address this, we define our dependent variable in two ways. First, the survey instrument used in SIPU looks at the probability of applying for a patent for firms' most commercially valuable innovation. The reasoning here is that an innovation which makes the most money for the company is also the innovation that it is most likely to be worth protecting through formal IP. Second, while the number of innovations of a firm is not observable, many respondents can say with some degree of certainty what percentage of their innovations is protected by patents and other formal IP strategies. This is an effective way of descaling patenting. The survey instrument in UKIS 2015 asks exactly this kind of a question.

Table 2 reports the simple average for the share of revenues due to innovation reported in UKIS and SIPU.

Table 2 Share of innovative sales in CIS and SIPU, all figures in \%

\begin{tabular}{lrlrll}
\hline & $N$ & $\begin{array}{l}\text { Contribution of innovation } \\
\text { to turnover in 2014 } \\
\text { (UKIS) }\end{array}$ & $N$ & $\begin{array}{l}\text { Contribution of the most } \\
\text { valuable innovation to } \\
\text { turnover in 2014 } \\
\text { (SIPU) }\end{array}$ & $\begin{array}{l}\text { Contribution of most } \\
\text { valuable innovation to } \\
\text { overall innovative sales in 2014 } \\
\text { (SIPU/UKIS) }\end{array}$ \\
\hline All firms & 269 & 37.2 & 246 & 21.7 & 58.3 \\
Small firms & 142 & 41.4 & 133 & 28 & 67.6 \\
Medium firms & 89 & 33.1 & 80 & 16.7 & 50.5 \\
Large firms & 38 & 31.2 & 33 & 8.4 & 26.9 \\
\hline
\end{tabular}

Sources: Authors' computations on SIPU 2015 merged with UKIS 2015 
Although the sets of figures are not directly comparable, firms' most valuable innovation accounts for more than half of all innovative sales on average and especially for small and medium firms. ${ }^{5}$ Thus, we expect that these are innovations which firms will try to protect using formal intellectual property instruments. In Table 3, we can also see that firms that reported using patents to protect their innovations in the UKIS also tended to report using patent protection to protect their most valuable innovation and vice versa: about $85 \%$ of the firms lie on the leading diagonal. This suggest that firms that use patents to protect technology and markets for their most valuable innovation are also likely to do so more generally. Understanding the barriers to patenting firms' most valuable innovation should therefore provide a good guide to more general barriers to patenting.

\subsection{Empirical approach}

Our empirical strategy uses information on different dimensions of firms' patenting activity to explore the impact of the propensity to patent and portfolio effects. First, to test Hypothesis 1, we estimate a model where the dependent variable PAT is a dummy variable equal to 1 if firm $i$ patented any innovation and zero otherwise:

$\operatorname{PAT}_{i}=\alpha_{0}+\alpha_{1} \mathrm{SIZE}_{1}+\alpha_{2} x_{i}+\varepsilon_{i}$

where SIZE is a set of dummy variables relating to the size of company $i$, and $x$ is a set of other firm-level controls such as whether a firm was product innovator and process innovator, undertook R\&D activity, and introduced new to market innovations. $\varepsilon$ is an idiosyncratic error term. ${ }^{6}$ The coefficient $\alpha_{1}$ will reflect the combined propensity to patent and portfolio effect. We also include a set of industry dummy variables in each model (see Annex 3). The equation is estimated at the firm level using UKIS data and samples constructed from all UKIS and comparable SIPU firms.

To test Hypothesis 2, we estimate a broadly similar model in which the dependent variable is defined to

\footnotetext{
${ }^{5}$ The two sets of figures are not strictly comparable as the data from UKIS relates to innovations introduced in the 3-year period from 2012 to 2014; however, $29 \%$ of the firms in SIPU (79 of 277 firms) reported that their most valuable innovation occurred before 2012 .

${ }^{6}$ The UK Innovation Survey (and SIPU) data sets provide a range of useful controls but have no indicators of ownership or firm age. Both may be important in shaping innovation outputs. Note however that the UK Innovation Survey is restricted to firms with 10 or more employees and so excludes smaller (and potentially young) start-up firms.
}

represent the propensity to patent (independent of any portfolio effect). Let $\mathrm{PROPPAT}_{i}$ represent firms' propensity to patent:

$\operatorname{PROPPAT}_{i}=\beta_{0}+\beta_{1} \mathrm{SIZE}_{1}+\beta_{2} x_{i}+\varepsilon_{i}$

We estimate two versions of this model to examine the relationship between propensity to patent and firm size. First, we use a binary dependent variable indicating whether firms patented their single most valuable innovation using innovation level controls (e.g., whether the innovation was product or process, new to market and financed externally). Second, we use a dependent variable measuring the proportion of firms' innovation portfolio which is protected by patents. In each case, coefficient $\beta_{1}$ will capture the relationship between firm size and the propensity to patent.

Our third set of regressions aims to explain the barriers to patent usage in the following way:

BARRIER $_{i}^{k}=b_{0}+b_{1} \operatorname{SIZE}_{i}+\delta x_{i}+\varepsilon_{i}$

where BARRIER stands for a set of $k$ dummy variables $(0 / 1)$ that denote the different types of barriers that firms have indicated as relevant for the decision not to patent their most valuable innovation. Models also include industry dummies (see Annex 3).

A range of different reasons for not patenting the most valuable innovation were specified in SIPU, and firms were allowed to tick more than one reason. ${ }^{7}$ In order to obtain a more parsimonious specification, we grouped the reasons for not patenting into three categories:

- Non-patentable innovation: which includes the following motivations: (a) innovation was not eligible for patenting, (b) patenting was not considered important by the firm, (c) innovation was not new to the market.

- Non-enforceable patent: which includes (a) the patent would have been difficult to enforce, (b) infringement of the patent would have been hard to

\footnotetext{
${ }^{7}$ The reasons for not patenting that respondents could choose included their innovation was not new to the market; the innovation was not eligible for patent protection; the cost of patent application was too high; a patent would have disclosed too much; infringement of the patent would be difficult to detect; and the patent would have been difficult to enforce. In addition, there was a free form field where firms could enter other reasons not included on the list. We parsed the reasons given into existing categories and added a new category that patenting was not considered relevant.
} 
Table 3 Use of patents in CIS and SIPU

\begin{tabular}{llcc}
\hline Used patents at all (UKIS) $\begin{array}{l}\text { Patented the most } \\
\text { valuable innovation } \\
\text { (SIPU) }\end{array}$ & \\
\cline { 2 - 3 } & No & Yes & All firms \\
& 144 & 7 & 151 \\
No & 29 & 64 & 93 \\
Yes & 173 & 71 & 244 \\
All firms & & \\
\hline
\end{tabular}

Sources: Authors' computations on SIPU 2015 merged with UKIS 2015

detect, and (c) patent would have disclosed too much

- High cost of patenting: for firms that reported that the cost of patent was too high.

Out of a total number of 206 firms that did not patent their most valuable innovation, 198 (82\%) indicated one of the three motivations above as a reason for their decision. ${ }^{8}$ Figure 1 shows that the most common reason for not patenting is that the innovation is not patentable (approximately $73 \%$; for $58 \%$ this was the only reason), followed by problems related to the fact that the patent was not enforceable or disclosed too much information $(33 \%)$. Cost-related reasons are instead a relatively lower concern for SIPU firms, with only $13 \%$ of firms indicating among the possible reasons and only $3 \%$ of the firms indicating it as the only reason. ${ }^{9}$ For each of the three barriers, we estimate a specific regression model (2) where the dependent variable is equal to 1 if that specific barrier was picked by the firm.

By looking at all three sets of regressions, we get a more holistic picture of the barriers to the use of formal IP. This marks a departure from past studies which have tended to infer the barriers to patent use from the first set of regressions alone (on patent propensity). We use the regression analysis mainly to produce conditional means that control for a wide range of characteristics/ attributes of the firm and the innovation. Annex 2 details the main variables we used in the analysis for each set of

\footnotetext{
${ }^{8}$ The remaining 8 firms either reported that the innovation was still not fully developed (and the patent application procedure had not been started yet), or did not report a specific reason.

${ }^{9}$ The graph also shows that a non-negligible number of firms (20\%) indicated a combination of the three (or two) reasons rather than a single one, suggesting that in some cases, different factors matter at the same time.
}

regressions, as well as the data source from which they are drawn.

\section{Results}

4.1 Patent propensity at firm and innovation level

Comparing the use of patents for all innovations by firms in UKIS 2015 and the probability of patenting their most valuable innovation from SIPU suggests some significant differences (Table 4). The existing evidence, suggesting that on average small firms have a lower patent propensity with respect to medium and large firms, is indeed confirmed by the statistics from UKIS firms. Table 4, column (2) shows that the share of small-firm innovators who applied for at least one patent in the UKIS is less than $20 \%$, significantly different in statistical terms from the share of innovators who patent among medium firms (26.5\%) and large firms (33\%). These differences reflect both the propensity to patent individual innovations and the breadth of firms' portfolio of innovations. When, however, we focus only on the most significant innovation, removing any portfolio effect (Table 5a, column 4), we find that there are no large differences among firms of different size, i.e., among the SIPU innovators, we find no evidence of size effects in the propensity to patent their most valuable invention. A first explanation of these results could be that, considering that patenting is a costly strategic decision taken by firms, financially constrained small firms will only apply for a patent when the value of their innovation is sufficiently high to motivate their investment.

The lack of any difference in patenting propensity between larger and smaller firms is not, however, combined to their most valuable innovation. An alternative approach to looking at patenting propensity separate from the portfolio effect is to examine the proportion of all innovations protected by patents. Again, this provides a way of de-scaling the data and adjusting for the fact that due to resource limitations, small firms may produce fewer innovations than large firms (Table 5). As noted earlier, Table 5 shows that a larger proportion of small firms do not use patents to protect their innovations. However, the proportion of small firms that depend on patents to protect more than $50 \%$ of their innovations does not seem significantly different to the average or to that in medium and large firms. 


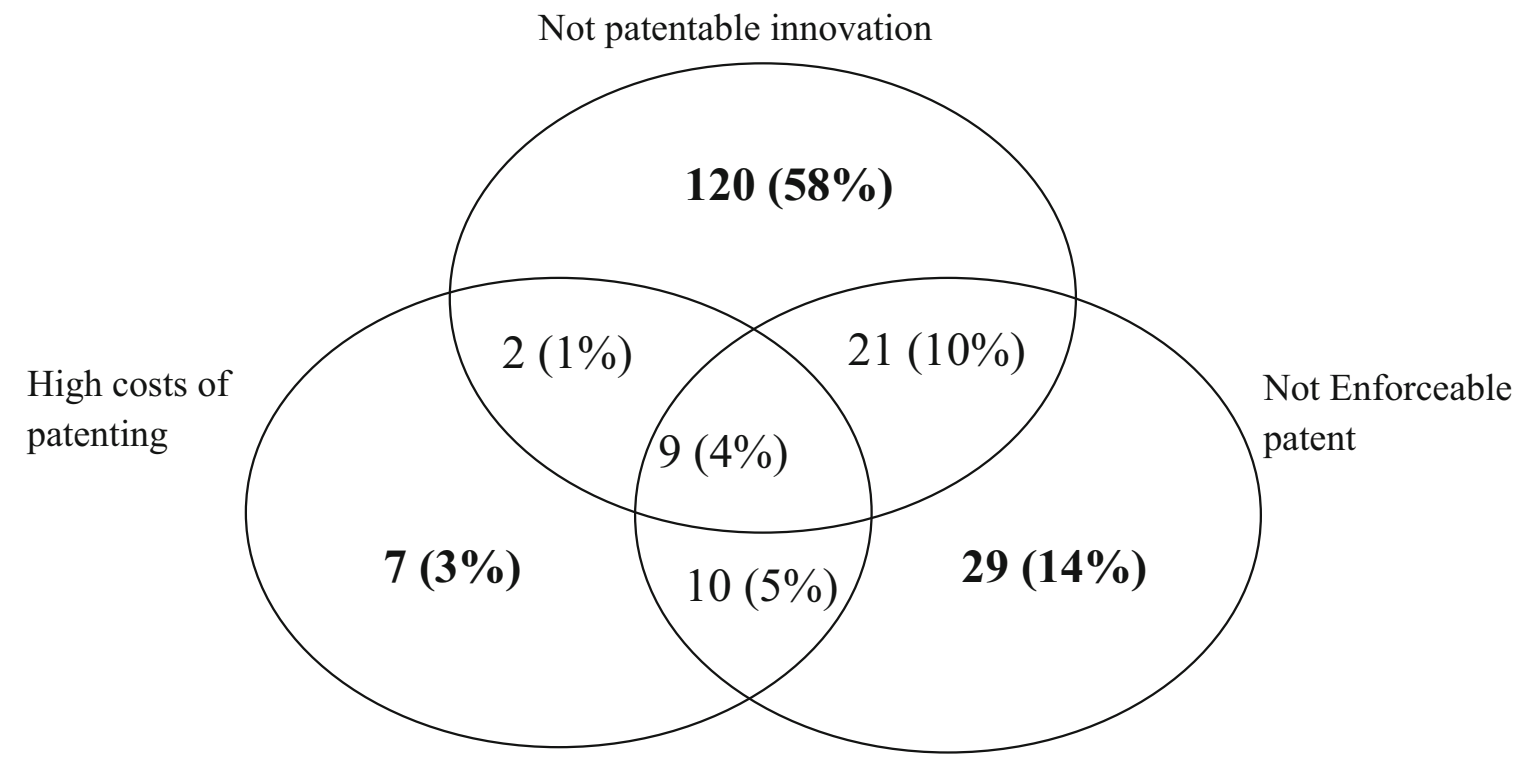

Fig. 1 Summary of firms' reasons for not patenting. $N=206(100 \%)$; in 8 cases, (4\%) none of the three reasons was specified as important (other reasons were specified as important). Source SIPU

To examine these differences in a multivariate context, controlling for factors such as the industry affiliation of the firm, R\&D activities, access to external finance, and type of innovation introduced, we use regression and probit analysis (Table 6). Both the SIPU and UKIS survey datasets are cross sectional, so here we

Table 4 Percentage of innovators applying for patents in the UKIS 2015 and in SIPU for their most valuable innovation

\begin{tabular}{|c|c|c|c|c|}
\hline & \multicolumn{2}{|c|}{ Patents all CIS innovators } & \multicolumn{2}{|c|}{ Patents SIPU } \\
\hline & \multicolumn{2}{|l|}{ (1) } & \multicolumn{2}{|l|}{ (2) } \\
\hline & Num. & $\%$ & Num. & $\%$ \\
\hline Total innovating firms & 2641 & & 277 & \\
\hline Total patenting firms & 666 & 25.22 & 71 & 25.63 \\
\hline Small firms (<49 employees) & 197 & $19.58 * * *$ & 35 & 24.8 \\
\hline Medium firms (50-249 employees) & 285 & $26.46 * * *$ & 25 & 27.2 \\
\hline Large Firms (> 250 employees) & 184 & $32.97 * * *$ & 11 & 25 \\
\hline Product innovation & 546 & $35.23 * * *$ & 57 & $33.1 * *$ \\
\hline Process innovation & 381 & 21.04 & 10 & 18.9 \\
\hline New to market & 397 & 43.77*** & 44 & $32.5^{* *}$ \\
\hline New to firm & 328 & 23.4 & 10 & 14.3 \\
\hline Continuous R\&D & 451 & $38.06 * * *$ & 49 & $34.75 * * *$ \\
\hline No $R \& D$ or discontinuous $R \& D$ & 215 & 14.77 & 22 & 16.18 \\
\hline Independent firms & - & - & 30 & 20.6 \\
\hline Affiliated to a group & - & - & 41 & $31.3 * *$ \\
\hline Internally financed & - & - & 46 & 22.1 \\
\hline Any external finance & - & - & 23 & $40.4 * * *$ \\
\hline
\end{tabular}

Source: Computations from UKIS 2015 and SIPU 2015. **Ssignificance at 5\%; ***Significance at $1 \%$ 
Table 5 Percentage of innovations protected by patents in UKIS 2015 for different groups of firms — percent of firms and number of firms in parentheses

\begin{tabular}{|c|c|c|c|c|c|c|}
\hline & \multicolumn{6}{|c|}{ Percentage of innovations protected } \\
\hline & None & $<10 \%$ & 10 to $40 \%$ & 41 to $60 \%$ & 61 to $90 \%$ & $>90 \%$ \\
\hline All innovating firms & $75.50(2009)$ & $9.39(250)$ & $4.81(128)$ & $2.71(72)$ & $2.48(66)$ & $5.11(136)$ \\
\hline Small firms & $81.51(829)$ & $5.31(54)$ & $2.56(26)$ & $2.16(22)$ & $2.75(28)$ & $5.70(58)$ \\
\hline Medium firms & $74.05(802)$ & $10.71(116)$ & $5.91(64)$ & $2.77(30)$ & $2.22(24)$ & $4.34(47)$ \\
\hline Large firms & $67.38(378)$ & $14.26(80)$ & $6.77(38)$ & $3.57(20)$ & $2.50(14)$ & $5.53(31)$ \\
\hline Product innovator & $65.71(1025)$ & $13.21(206)$ & $6.86(107)$ & $3.78(59)$ & $3.40(53)$ & $7.05(110)$ \\
\hline Process innovators & $79.68(1455)$ & $7.78(142)$ & $4.05(74)$ & $2.46(45)$ & $2.19(40)$ & $3.83(70)$ \\
\hline New to market & $57.53(527)$ & $14.30(131)$ & $8.95(82)$ & $5.02(46)$ & $4.59(42)$ & $9.61(88)$ \\
\hline New to firm & $77.28(1092)$ & $10.26(145)$ & $4.60(65)$ & $2.48(35)$ & $1.98(28)$ & $3.40(48)$ \\
\hline Continuous R\&D & $62.62(747)$ & $13.50(161)$ & $8.47(101)$ & $3.94(47)$ & $4.11(49)$ & $7.38(88)$ \\
\hline No R\&D or discontinuous R\&D & $79.65(454)$ & $8.42(48)$ & $3.33(19)$ & $2.63(15)$ & $1.93(11)$ & $4.04(23)$ \\
\hline
\end{tabular}

Source: Authors' computations from UKIS 2015

use regression analysis as a purely descriptive (rather than causal) tool to assess if there are differences between small and large firms in their probability of patenting. Table 6 , model 1 reports the conditional

Table 6 Patent propensity among innovating firms

\begin{tabular}{|c|c|c|c|c|c|}
\hline & (1) & $(2)$ & (3) & (4) & (5) \\
\hline $\begin{array}{l}\text { Dependent } \\
\text { variables }\end{array}$ & $\begin{array}{l}\text { Probability of patenting } \\
\text { any innovation }\end{array}$ & $\begin{array}{l}\text { Probability of patenting } \\
\text { any innovation }\end{array}$ & $\begin{array}{l}\text { Probability of patenting most } \\
\text { valued innovation }\end{array}$ & $\begin{array}{l}\text { Share of } \\
\text { innovations } \\
\text { patented }\end{array}$ & $\begin{array}{l}\text { Share of } \\
\text { innovations } \\
\text { patented }\end{array}$ \\
\hline Sample & UKIS & SIPU & SIPU & UKIS & SIPU \\
\hline Estimation method & Probit & Probit & Probit & OLS & OLS \\
\hline Continuous R\&D & $\begin{array}{l}0.135 * * * \\
(0.019)\end{array}$ & $\begin{array}{l}0.182 * * * \\
(0.069)\end{array}$ & $\begin{array}{l}0.110 * * \\
(0.045)\end{array}$ & $\begin{array}{l}0.054 * * * \\
(0.011)\end{array}$ & $\begin{array}{l}0.071^{*} \\
(0.036)\end{array}$ \\
\hline $\begin{array}{l}\text { Small firm }(<49 \\
\text { employees })\end{array}$ & $\begin{array}{l}-0.126^{* * *} \\
(0.021)\end{array}$ & $\begin{array}{l}-0.274 * * * \\
(0.093)\end{array}$ & $\begin{array}{l}-0.04 \\
(0.066)\end{array}$ & $\begin{array}{l}-0.016 \\
(0.013)\end{array}$ & $\begin{array}{l}0.000 \\
(0.048)\end{array}$ \\
\hline $\begin{array}{l}\text { Medium firm } \\
\qquad(50-249 \text { emps })\end{array}$ & $\begin{array}{l}-0.067 * * * \\
(0.021)\end{array}$ & $\begin{array}{l}-0.268^{* * *} \\
(0.082)\end{array}$ & $\begin{array}{l}-0.037 \\
(0.064)\end{array}$ & $\begin{array}{l}-0.022^{*} \\
(0.013)\end{array}$ & $\begin{array}{l}-0.027 \\
(0.045)\end{array}$ \\
\hline $\begin{array}{c}\text { Innovation } \\
\text { externally } \\
\text { financed }\end{array}$ & & & $\begin{array}{l}0.222 * * * \\
(0.076)\end{array}$ & & \\
\hline Product innovator & $\begin{array}{l}0.130 * * * \\
(0.022)\end{array}$ & $\begin{array}{l}0.287 * * * \\
(0.071)\end{array}$ & $\begin{array}{l}-0.07 \\
(0.043)\end{array}$ & $\begin{array}{l}0.024 * \\
(0.012)\end{array}$ & $\begin{array}{l}0.126^{* * * *} \\
(0.043)\end{array}$ \\
\hline Process innovator & $\begin{array}{l}-0.042 * \\
(0.022)\end{array}$ & $\begin{array}{l}0.181 * * * \\
(0.068)\end{array}$ & $\begin{array}{l}-0.122 * * * \\
(0.044)\end{array}$ & $\begin{array}{l}-0.027 * \\
(0.014)\end{array}$ & $\begin{array}{l}0.130 * * * \\
(0.048)\end{array}$ \\
\hline $\begin{array}{l}\text { New to market } \\
\text { Innovator }\end{array}$ & $\begin{array}{l}0.177 * * * \\
(0.020)\end{array}$ & $\begin{array}{l}0.232 * * * \\
(0.066)\end{array}$ & $\begin{array}{l}0.047 \\
(0.043)\end{array}$ & $\begin{array}{l}0.094 * * * \\
(0.012)\end{array}$ & $\begin{array}{l}0.133 * * * \\
(0.037)\end{array}$ \\
\hline Observations & 2618 & 268 & 277 & 2641 & 291 \\
\hline Pseudo $R^{2} / R^{2}$ & 0.154 & 0.236 & 0.185 & 0.088 & 0.19 \\
\hline Log likelihood & -1483 & -176.5 & -157.7 & -50.37 & -53.39 \\
\hline
\end{tabular}

Models include a set of industry dummies — not reported (see Annex 2)

Notes: $*$ for significance at $10 \%$; ** for significance at $5 \%$; *** for significance at $1 \%$ 
probability of a firm obtaining a patent in the UKIS sample of innovators, around 2600 firms. The reference group in the model is larger firms, and we find the familiar result that small and medium firms are less likely to patent. Small firms are $12.6 \%$ less likely to be patenting than large firms, a gap which falls to $6.7 \%$ for medium firms (Table 6, model 1). We see a similar result for the smaller group of firms which are included in the SIPU dataset (Table 6, model 2). Here again small and medium firms are significantly less likely to be patenting than larger firms. These differences in the probability of patenting at firm-level reflect the combination of the portfolio and propensity to patent effect, and provide strong confirmation of Hypothesis 1.

Hypothesis 2 reflects the propensity to patent firms' innovations excluding any portfolio effect. We test this proposition in two ways. First, by focusing on whether there is any difference in large firms' and small firms' propensity to patent their most valuable innovation and, secondly, by exploring whether there is any difference in the proportion of firms' portfolio of innovations is patented. Table 6 , model 3 focuses on the propensity to patent firms' most valuable innovation which we are only able to estimate for the smaller SIPU sample. ${ }^{10}$ In line with the descriptive results in Table 5, we find here that being a small firm (less than 50 employees) does not significantly decrease the propensity to patent the firms' most valuable innovation. Note, however, that both for small and medium firms, coefficients are negative but insignificant. The implication is that there is no significant difference in the probability that smaller firms and large firms will patent their most valuable innovation, and that it is therefore the portfolio effect rather than the propensity to innovate effect which explains the difference between the probability of small and large firm patenting.

A second test of Hypothesis 2 is provided by the models in Table 6 columns 4 and $5 .{ }^{11}$ Here, we directly de-scale the patenting data by looking at the proportion of firms' innovations protected by patents. Again, this focuses attention on the propensity to patent and

\footnotetext{
${ }^{10}$ Among the other control variables, we also include some new variables not included in Table 5 but which have been suggested by the literature on patenting. Additionally, we check for the effect of openness, i.e., the fact that a firm develops its most important innovation collaboratively with other external partners, and we find that it exerts a negative effect on patenting.

${ }^{11}$ Table 6 reports OLS estimates but we found qualitatively similar results using fractional logit models (not reported here). These results are available from the authors upon request.
}

removes any portfolio effect. Here again, in both the (larger) UKIS and (smaller) SIPU samples, we find no significant difference in the proportion of small and larger firms' innovations which are protected by patenting (Table 6 , models 4 and 5 ). The very similar results here obtained for both the larger UKIS and smaller SIPU samples also suggest that this result is not simply a consequence of differences in sample size in the SIPU and UKIS surveys. Instead, our result of the insignificance of the difference in the proportion of patented innovations in larger and small firms proves robust in both samples. Taken together, our analysis therefore provides strong support for Hypothesis 2 and the idea that small and large firms have similar patent propensity.

\subsection{Barriers to patenting}

We turn now to the discussion of why firms may not patent their valuable innovation. Using data from the smaller SIPU sample, we consider the responses of all firms that reported a valuable innovation, but did not patent that innovation (Table 7). The three most important reasons for not patenting were the innovation could not be patented $(68 \%)$, followed by the patent would have been difficult to enforce (31\%), and lack of novelty $(30 \%)$. Interestingly, these three reasons continue to be the main reasons for not patenting even when we look across the different groups of firms. ${ }^{12}$ The fear that patents would disclose too much was the least frequently reported reason for not patenting $(4 \%)$.

The next three columns in Table 7 look at the reasons for not patenting by firm size. Statistically significant differences are highlighted in italic. In general, the reasons for not patenting the most valuable innovation were similar between medium and large firms. Medium and large firms were more likely not to patent because their innovations could not be protected by patents, especially when compared to small firms. Large firms often have in-house legal advisors and this may make them more aware of the patentability of innovations. One in five

\footnotetext{
$\overline{12}$ Our summary category of non-patentable innovation includes three sub-categories identified in the SIPU survey: (a) innovation was not eligible for patenting, (b) patenting was not considered important by the firm, and (c) innovation was not new to the market. It is notable that (b) was ranked as relevant only by $8.2 \%$ of the population of firms and small firms were not significantly different from the average. Patentability is a significant reason for not patenting but this is not a reason reported disproportionately often by small firms.
} 
Table 7 Reasons for not patenting given by innovating firms (\% of firms choosing each reason)

\begin{tabular}{|c|c|c|c|c|c|c|c|c|c|c|c|}
\hline \multirow{2}{*}{$\begin{array}{l}\text { Reasons for not patenting } \\
\begin{array}{l}\text { The innovation was not } \\
\text { eligible for patent protection }\end{array}\end{array}$} & \multicolumn{2}{|c|}{$\begin{array}{l}\text { Non- } \\
\text { patenting } \\
\text { firms } \\
(n=206)\end{array}$} & \multirow{2}{*}{$\begin{array}{l}\text { Small } \\
\text { firms } \\
62.3\end{array}$} & \multirow{2}{*}{$\begin{array}{l}\text { Medium } \\
\text { Firms } \\
76.1\end{array}$} & \multirow{2}{*}{$\begin{array}{l}\begin{array}{l}\text { Large } \\
\text { firms }\end{array} \\
69.7\end{array}$} & \multirow{2}{*}{$\begin{array}{l}\text { Product } \\
\text { innovators } \\
62.6\end{array}$} & \multirow{2}{*}{$\begin{array}{l}\text { Process } \\
\text { innovators } \\
72.1\end{array}$} & \multirow{2}{*}{$\begin{array}{l}\text { Not } \\
\text { continuous } \\
\text { R\&D } \\
75.4\end{array}$} & \multirow{2}{*}{$\begin{array}{l}\text { Continuous } \\
\text { R\&D } \\
58.7\end{array}$} & \multirow{2}{*}{$\begin{array}{l}\text { Not } \\
\text { Open } \\
75.7\end{array}$} & \multirow{2}{*}{ Open } \\
\hline & 140 & 67.9 & & & & & & & & & \\
\hline $\begin{array}{l}\text { The patent would have been } \\
\text { difficult to enforce }\end{array}$ & 64 & 31.1 & 34.9 & 26.8 & 27.2 & 33.0 & 39.5 & 25.4 & 38.1 & 28.3 & 32.5 \\
\hline $\begin{array}{l}\text { Innovation was not new to the } \\
\text { market }\end{array}$ & 62 & 30 & 33.0 & 28.4 & 24.2 & 23.5 & 41.9 & 37.7 & 20.7 & 31.1 & 29.5 \\
\hline $\begin{array}{l}\text { The cost of patent application } \\
\text { was too high }\end{array}$ & 28 & 13.5 & 20.8 & 7.5 & 3.0 & 18.3 & 11.6 & 7.9 & 20.7 & 13.5 & 13.6 \\
\hline $\begin{array}{l}\text { Infringement of the patent } \\
\text { would be difficult to detect }\end{array}$ & 21 & 10.2 & 11.3 & 9.0 & 9.1 & 12.2 & 9.3 & 9.6 & 10.9 & 12.2 & 9.1 \\
\hline Patent was not relevant & 17 & 8.2 & 8.5 & 10.4 & 3.0 & 9.6 & 0.0 & 12.3 & 3.3 & 4.1 & 10.6 \\
\hline $\begin{array}{l}\text { A patent would have disclosed } \\
\text { too much }\end{array}$ & 8 & 3.8 & 6.6 & 1.5 & 0.0 & 4.3 & 4.7 & 2.6 & 5.4 & 2.7 & 4.5 \\
\hline Other & 4 & 1.9 & 0.9 & 3.0 & 3.3 & 2.6 & 0.0 & 0.8 & 3.3 & 1.4 & 2.3 \\
\hline
\end{tabular}

Values in italic identify statistically significant differences. Source: Computations from SIPU2015

Table 8 Probit models of reasons for not patenting

\begin{tabular}{|c|c|c|c|}
\hline & (1) & (2) & (3) \\
\hline Dependent variables & Not patentable & Not enforceable & High costs \\
\hline Sample & SIPU & SIPU & SIPU \\
\hline Estimation method & Probit & Probit & Probit \\
\hline \multirow[t]{2}{*}{ Value of invention } & -0.021 & $0.057 * * *$ & 0 \\
\hline & $(0.021)$ & $(0.021)$ & $(0.000)$ \\
\hline \multirow[t]{2}{*}{ Continuous R\&D } & $-0.132 *$ & 0.049 & 0 \\
\hline & $(0.072)$ & $(0.077)$ & $(0.000)$ \\
\hline \multirow[t]{2}{*}{ Small firm (<49 employees) } & 0.055 & -0.019 & $0.183 * * *$ \\
\hline & $(0.110)$ & $(0.121)$ & $(0.068)$ \\
\hline \multirow[t]{2}{*}{ Medium firm (50-249 emps) } & 0.156 & -0.068 & $0.477 * * *$ \\
\hline & $(0.097)$ & $(0.117)$ & $(0.097)$ \\
\hline \multirow[t]{2}{*}{ Any external finance } & -0.03 & -0.091 & 0 \\
\hline & $(0.091)$ & $(0.080)$ & $(0.000)$ \\
\hline \multirow[t]{2}{*}{ Process innovation } & 0.003 & -0.034 & 0 \\
\hline & $(0.085)$ & $(0.091)$ & $(0.000)$ \\
\hline \multirow[t]{2}{*}{ Business strategy } & $0.142 * *$ & $-0.140 *$ & -0.004 \\
\hline & $(0.070)$ & $(0.085)$ & $(0.003)$ \\
\hline \multirow[t]{2}{*}{ New to the market innovation } & $-0.142 * *$ & $0.190 * * *$ & 0 \\
\hline & $(0.065)$ & $(0.073)$ & $(0.000)$ \\
\hline \multirow[t]{2}{*}{ Openness (dummy) } & -0.041 & -0.013 & 0 \\
\hline & $(0.063)$ & $(0.075)$ & $(0.000)$ \\
\hline Observations & 197 & 197 & 197 \\
\hline Pseudo $R^{2} / R^{2}$ & 0.225 & 0.149 & 0.373 \\
\hline Log likelihood & -88.07 & -103 & -49.39 \\
\hline
\end{tabular}

Models include a set of industry dummies — not reported (see Annex 2) 
small firms (20\%) reported not patenting because they found the cost of patenting to be too high (as compared to $7 \%$ of medium and $3 \%$ of large firms). This latter finding is consistent with the literature on small firms reviewed in Hughes and Mina (2010) which identifies the cost of patenting to be the single largest obstacle to the use of patents by small firms.

In order to understand which factors are associated with each of the motivations for not patenting, we restrict our analysis to firms from the SIPU survey who innovated but did not apply for a patent for their most valuable innovation (Table 8 ). We run three separate probit models, as outlined in Eq. (2): for each of them, we use as dependent variable whether the innovation was "not," "not enforcable," or "high costs."13 The independent variables consist of all the other characteristics of the firm and innovation that we have introduced in the previous sections as likely to influence each of the motivations. In particular, these include the size of each firm, whether the firm performs R\&D activities, the general propensity of a firm to patent its innovations, the specific value of the innovation, the type of innovation introduced (whether a product or process innovation, or a new business strategy), the novelty of the innovation (new to the market or new only for the firm), the specific source of financing for the innovation , and whether a collaboration put in place to develop the valuable innovation. ${ }^{14}$

Our estimation suggests no significant difference in the patentability of small and larger firms most valuable innovation (Table 8, model 1). Innovation quality-at least in terms of firms' most valuable innovation-

\footnotetext{
${ }^{13}$ Since we show that some of the reasons were jointly considered as important by some firms, we also checked whether the use of a trivariate probit model, which allows for the correlation between the error terms of each model, was more appropriate. The results showed that indeed there is some correlation between the error terms of the three models, in particular there is a positive and significant correlation between the error term of the non-enforceable patent model and the high cost of patenting specification. However, the signs and significance of the trivariate probit model are perfectly in line with those obtained running three separate probit analyses. Since in the case of the trivariate probit, it is not straight forward to calculate marginal effects for each of the independent variables, we eventually decided to report marginal effects from the separate probit models, which are much easier to interpret.

${ }^{14}$ In the regressions, we only use 190 observations instead of 206, because some firms did not answer to some of the questions in the survey that we use to build our independent variables ( 7 firms did not answer to the question related to financing sources, while other 9 did not indicate the specific type of innovation). For this reason, 16 observations could not be used in the empirical analyses.
}

appears not to be a significantly greater barrier to patenting in smaller firms. Similarly, the enforceability of patents is not seen as a stronger barrier to patenting in smaller firms (Table 8, model 2). As suggested by Table 7 , however, high costs of patenting were more commonly cited as a barrier to patenting their most valuable innovation by smaller and medium-sized firms (Table 8, model 3). Interestingly, this effect remained unchanged whether or not firms were using external finance to fund their innovation activity. Our results provide support for Hypothesis 3: smaller firms do have a stronger perception of cost barriers to using patents as a means of protecting their most valuable innovations.

\section{Conclusions}

It is a widely held view that small firms patent less than large firms (Hall et al., 2013; Pajak, 2016). In this paper, we analyze whether this is simply because small firms have fewer innovations or because they are less likely to patent any specific innovation (due to lower patent propensity) or because the costs of owning and enforcing patents are too high. Using novel data which combine innovation and firm level information, our paper tries to disentangle these three sources of difference which could result in the observed lower patenting behavior of small firms.

Our empirical results suggest three key findings. First, confirming evidence from other studies, we too find that smaller firms are less likely to be patenting than larger firms. However, using data on individual innovations, our analysis also suggests that smaller firms are no less likely than large firms to patent any specific innovation or proportion of their innovations. In other words, the propensity to patent any specific innovation is broadly similar in firms of all sizes. The implication is that differences in the probability that smaller and larger firms will patent relate not to a "propensity to patent" effect but primarily to the "'effect." i.e., larger firms create a greater number of innovations than smaller firms and therefore are simply more likely to create one or more which are patentable. This is consistent with studies of innovation survey data which consistently suggest a positive relationship between firm size and the likelihood, volume, and novelty of innovation. Our third finding is that where firms do not patent specific innovations, it is cost barriers rather than issues related 
to the awareness of patenting or innovation quality which are driving any firm size differences.

Our results paint a picture where small firms which have patentable innovations of actual or potential commercial value are equally likely to patent these as larger firms. Policy concerns about lower patenting rates among smaller firms may therefore be misplaced being instead a natural consequence of firm size differences and the fact that large firms typically have a larger number of patentable innovations. Issues do remain, however, about small firms engagement with patenting particularly as small firms are more likely to cite cost barriers to patenting than larger firms (Table 8), and any cost reductions may therefore have a disproportionate effect on smaller firms. Yet, although the costs of patenting are well known and understood (WIPO, undated), this is an area where policy measures are limited. For example, in the UK,. patenting and trade mark costs are explicitly excluded from the eligible expenses which are covered by $R \& D$ tax credits for all sizes of firms although these costs may be offset using other tax breaks. ${ }^{15}$ Most policy initiatives targeted at small firms have instead concentrated on creating awareness and educating small firms about the value of patenting. Helping smaller firms to offset the costs of obtaining patents by extending the eligible expenses for R\&D tax credits would increase patent use by smaller firms. Alongside this, it has been suggested that small firms may be helped by establishing patent litigation insurance schemes which could help with the costs of defending patents (CJA Consultants Ltd, 2006) with some countries (China, Japan) offering subsidies to small firms to join private IP insurance schemes (EUIPO, 2018, p. 6).

At a more general level, our results suggest the value of combining firm-level and innovation-level data. Innovation-level data can provide more detailed insights into firms' decision rules as they applied to a specific project, effects which are obscured where firms are making decisions about a portfolio of innovations. Our study suffers from a number of limitations. First, our data is restricted to the $\mathrm{UK}$, and international replication would therefore be desirable. Second, we focus here on patenting in isolation, and it would also be valuable to explore potential complementary or substitute

\footnotetext{
${ }^{15}$ See https://www.gov.uk/guidance/corporation-tax-research-anddevelopment-tax-relief-for-small-and-medium-sizedenterprises\#costs-you-can-claim.
}

relationships between forms of IP protection. This may be particularly important for smaller firms where patent costs may encourage the adoption of less costly IP protection mechanisms. Third, our estimation sample drawn from the SIPU data is relatively small reducing the potential for sub-sample analysis. Larger samples would enable us to explore whether the general patterns we see in terms of portfolio and propensity effects prove generally robust. For example, it may be useful to consider separately the patenting behaviors of high growth firms and those in the more general SME population. Finally, future analyses could also use panel data to add robustness to our exploratory analysis: this may decrease the potential endogeneity problems that could affect our cross-sectional estimates. Such analyses could also explore interactions between patenting propensity and portfolio size which may arise as both may depend to some extent on the cost-benefit of patenting.

Acknowledgments We are grateful to the UK Intellectual Property Office for making available the survey data on which this paper is based. Sandeep Kapur (Birkbeck) provided valuable comments on an earlier draft. We are indebted to an anonymous reviewer for this journal who suggested a formal model supporting our hypotheses which we include in Annex 1. Other valuable comments were received from the editor and two further anonymous reviewers. Remaining errors are our own.

\section{Annex}

Annex 1. A formalization of the hypotheses

The paper contains three hypotheses that could belong into a single optimization problem written formally as follows:

$\operatorname{Max} V(P, N, p)=P\left(\pi^{\prime} p+\pi(1-p)\right)+(N-P) \pi-\Gamma(P)$

where $V$ is the expected profit of innovation to the firm (maximized over $P$ ), $N$ is the number of innovations the firm is able to create by virtue of its size (large/small). We assume $N$ is increasing in firm size so that $\mathrm{N}$ and firm size are synonymous.

$P$ is the number of patents the firm decides to apply for. $P / N \leq 1$, firms can at most patent all their innovations but usually only a fraction is patented because of the conditions surrounding the grant of a patent (viz., novelty and codifiability of technical knowledge).

$p$ is the probability that a submitted patent is granted, assumed to be exogenous and common to both large and 
small firms, although this assumption may be relaxed. In fact, $p$ may be a function of the maturity of the technology/ sector. More mature technologies may find it hard to find a truly novel innovation that can earn a patent, conversely new technologies may offer a lot of opportunity for patenting. The quality of a firm's R\&D projects may also influence $p$ and the received wisdom is that (unobservable) $\mathrm{R} \& \mathrm{D}$ management capabilities drive better project choice. Hence, in the way we estimate our model, we include both industrial sector dummies and whether a firm is a continuous $R \& D$ performer as controls for the potential influences on $p$.

Profits from an innovation that has patent protection $\left(\pi^{\prime}\right)$ can be assumed to exceed those from an innovation that is not protected $(\pi)$, so $\left(\pi^{\prime}-\pi\right)>0$.

$\Gamma$ is the fixed cost of patenting, which increases in the number of patent applications $(P)$ but has a fixed component $C$ that is incurred irrespective of whether the firm files one or many patents. This could be the costs of setting up an in-house IP department for a large firm or engaging a patent attorney over the length of a patent life to show a credible commitment to enforcing the patent, should it be infringed.

Annex 2.
The first order condition for this problem is:

$\partial V / \partial P=\left(\pi^{\prime}-\pi\right) p-\partial \Gamma(P) / \partial P$

This provides an interior solution for $P$, which describes an interior maximum if the second-order condition is negative. In other words, it must be true that the fixed costs of patenting are increasing at an increasing rate in $P$ for each firm.

We assume that $\Gamma(P)=C+P^{b}$ with $b \geq 2$.

Then the first-order condition implies that the equilibrium number of patents $P^{*}$ is:

$\mathrm{P} *=\left\{\frac{1}{b}\left(\pi^{\prime}-\pi\right) \mathrm{p}\right\}^{1 / \mathrm{b}-1}$

Notice that this equation does not involve $N$ (equivalently is independent of firm size in this simple formulation) and forms the basis for Hypothesis 2.

However, the fixed cost element in the cost function means that depending upon the size of the fixed cost, there will be a minimum threshold of patentable innovations that are needed before a firm applies for a patent. $C \leq\left(\pi^{\prime}\right) P^{*}$. This reasoning forms the basis for Hypothesis 3 .

Table 9 Variable definitions and sources

\begin{tabular}{|c|c|c|}
\hline Variable & Source of data & Description of the variable \\
\hline \multicolumn{3}{|l|}{$\begin{array}{l}\text { Dependent variable } \\
\text { (Table 6) }\end{array}$} \\
\hline Patent application & UKIS 2015 and SIPU 2015 & $\begin{array}{l}\text { Dummy variable }=1 \text { when respondent reports applying for a patent to } \\
\text { protect any innovation }\end{array}$ \\
\hline Patent application & SIPU 2015 & $\begin{array}{l}\text { Dummy variable }=1 \text { when respondent reports applying for a patent } \\
\text { to protect their most valuable innovation }\end{array}$ \\
\hline Patent coverage & UKIS 2015 and SIPU 2015 & Share of firms' innovations protected by patents $(\%)$ \\
\hline \multicolumn{3}{|l|}{$\begin{array}{l}\text { Dependent variables } \\
\text { (Table } 8 \text { ) }\end{array}$} \\
\hline Non-patentable innovation & SIPU 2015 & $\begin{array}{l}\text { Dummy variable }=1 \text {, if firm said any of the following reasons prevented } \\
\text { them from applying for a patent- (a) innovation was not eligible for } \\
\text { patenting, (b) patenting was not considered important by the firm, and } \\
\text { (c) innovation was not new to the market. }\end{array}$ \\
\hline Non-enforceable patent & SIPU 2015 & $\begin{array}{l}\text { Dummy variable }=1 \text {, if firm said any of the following reasons prevented } \\
\text { them from applying for a patent- (a) the patent would have been difficult } \\
\text { to enforce, (b) infringement of the patent would have been hard to detect } \\
\text { and (c) and patent would have disclosed too much }\end{array}$ \\
\hline
\end{tabular}

High cost of patenting SIPU 2015 
Table 9 (continued)

\begin{tabular}{|c|c|c|}
\hline Variable & Source of data & Description of the variable \\
\hline & & $\begin{array}{l}\text { Dummy variable }=1 \text {, if firm said high costs prevented them from } \\
\text { applying for a patent }\end{array}$ \\
\hline \multicolumn{3}{|l|}{ Firm-specific variables } \\
\hline Small firm & UKIS 2015 & Dummy variable $=1$, if the firm employed less than 50 persons \\
\hline Medium firm & UKIS 2015 & $\begin{array}{l}\text { Dummy variable }=1 \text {, if the firm employed between } 50 \\
\text { and } 249 \text { employees }\end{array}$ \\
\hline Large firm & UKIS 2015 & Dummy variable $=1$, if the firm employed more than 250 employees \\
\hline Continuous $\mathrm{R} \& \mathrm{D}$ & UKIS 2015 & $\begin{array}{l}\text { Dummy variable that takes value } 1 \text { if firms had undertaken internal } \\
\text { R\&D in } 2012,2013 \text {, and } 2014\end{array}$ \\
\hline Overall patent propensity & UKIS 2015 & $\begin{array}{l}\text { The proportion of innovations between } 2012 \text { and } 2014 \text { that was } \\
\text { protected by patents }\end{array}$ \\
\hline Overall trademark propensity & UKIS 2015 & $\begin{array}{l}\text { The proportion of innovations between } 2012 \text { and } 2014 \text { that was } \\
\text { protected by trademarks }\end{array}$ \\
\hline 17 Industrial sectors & UKIS 2015 & $\begin{array}{l}\text { Based on the 2-digit SIC and aggregated to get a minimum of } 20 \\
\text { observations per group. See Table } 1 \text { for details }\end{array}$ \\
\hline \multicolumn{3}{|c|}{ Innovation-specific variables (for the commercially most valuable innovation) } \\
\hline Openness & SIPU 2015 & $\begin{array}{l}\text { Dummy variable }=1 \text { when respondent reports' collaborative } \\
\text { partner was involved in producing its most valuable innovation }\end{array}$ \\
\hline Suppliers & SIPU 2015 & $\begin{array}{l}\text { Dummy variable }=1 \text { when respondent reports' collaboration with } \\
\text { supplier was involved in producing its most valuable innovation }\end{array}$ \\
\hline Clients & SIPU 2015 & $\begin{array}{l}\text { Dummy variable }=1 \text { when respondent reports' collaboration with } \\
\text { client was involved in producing its most valuable innovation }\end{array}$ \\
\hline Other types of collaboration & SIPU 2015 & $\begin{array}{l}\text { Dummy variable }=1 \text { when respondent reports' collaboration with } \\
\text { public sector labs, consultants, competitors, or HEI was involved } \\
\text { in producing its most valuable innovation }\end{array}$ \\
\hline Value of innovation & SIPU 2015 & Value of turnover (\%) in 2014 accounted for by the most valuable innovation \\
\hline Product innovation & SIPU 2015 & Dummy variable $=1$, if the most valuable innovation was a product innovation \\
\hline Process innovation & SIPU 2015 & $\begin{array}{l}\text { Dummy variable }=1 \text {, if the most valuable innovation was a process } \\
\text { innovation }\end{array}$ \\
\hline Business strategy innovation & SIPU 2015 & Dummy variable $=1$, if the most valuable innovation was a wider innovation \\
\hline $\begin{array}{l}\text { New to the market } \\
\text { innovation }\end{array}$ & SIPU 2015 & Dummy variable $=1$, if the most valuable innovation was a new to the market \\
\hline New to the firm innovation & SIPU 2015 & Dummy variable $=1$, if the most valuable innovation was new to the firm \\
\hline Any external finance & SIPU 2015 & $\begin{array}{l}\text { Dummy variable }=1 \text {, if the firm used any external finance to finance } \\
\text { its most valuable innovation }\end{array}$ \\
\hline
\end{tabular}


Annex 3

Table 10 Industry control variables included in all models

$1 \quad$ Food and textiles (SIC 2007 codes: 10131415 )

2 Wood and paper (SIC 2007 codes: 16 17)

3 Chemicals and rubber (SIC 2007 codes: 20 22)

$4 \quad$ Metal and non metal products (SIC 2007 codes: 2324 25)

5 Electrical and computing devices (SIC 2007 codes: 26 27)

6 Machines and repairing of (SIC 2007 codes: 28 33)

7 Automotive (SIC 2007 code: 29 30)

8 Other manufacturing (SIC 2007 codes: 1831 32)

9 Construction (SIC 2007 codes: 4142 43)

10 Whole sale and retail trade (SIC 2007 codes: 454647 )

11 Tourism (SIC 2007 codes: 55 56)

12 ICT (SIC 2007 codes: from 58 to 63 )

13 Financial services (SIC 2007 codes: 6465 66)

14 Professional and scientific tools (SIC 2007 codes: from 69 to 75)

15 Administrative activities (SIC 2007 codes: from 77 to 82)

16 Transport (SIC 2007 codes: from 49 to 53)

17 Other sectors

Open Access This article is licensed under a Creative Commons Attribution 4.0 International License, which permits use, sharing, adaptation, distribution and reproduction in any medium or format, as long as you give appropriate credit to the original author(s) and the source, provide a link to the Creative Commons licence, and indicate if changes were made. The images or other third party material in this article are included in the article's Creative Commons licence, unless indicated otherwise in a credit line to the material. If material is not included in the article's Creative Commons licence and your intended use is not permitted by statutory regulation or exceeds the permitted use, you will need to obtain permission directly from the copyright holder. To view a copy of this licence, visit http://creativecommons.org/licenses/by/4.0/.

\section{References}

Arora, A., Athreye, S., Huang, C. (2013) Innovation, patenting and licensing in the UK: evidence from the SIPU survey, $U K$ IPO Working Paper Series, 2013/25.

Arora, A., Ceccagnoli, M., Cohen, W.M., (2008) R\&D and the patent premium, International Journal of Industrial Organization 26,(5), 1153-1179.

Arundel, A. (2001). The relative effectiveness of patents and secrecy for appropriation. Research Policy, 30(4), 611-624.

Arundel, A., \& Kabla, I. (1998). What percentage of innovations are patented? Empirical estimates for European firms. Research Policy, 27, 127-141.
Athreye, S., \& Fassio, C. (2018). When do firms not use patents and trademarks to protect valuable innovations? Evidence from the SIPU 2015 survey. Newport: Intellectual Property Office.

Baumol, W. J. (2002). The free market innovation machine. Princeton Princeton University Press.

Bourke, J., \& Roper, S. (2016). AMT adoption and innovation: an investigation of dynamic and complementary effects. Technovation, 55-56, 42-55.

Bourke, J., \& Roper, S. (2017). Innovation, quality management and learning: short-term and longer-term effects. Research Policy, 46, 1505-1518.

CJA Consultants Ltd (2006) Patent litigation insurance - a study for the European Commission on the feasibility of possible insurance schemes against patent litigation risks.

Cohen, W. M., Nelson, R.R., and Walsh, J.P., (2000) Protecting their intellectual assets: appropriability conditions and why U.S. manufacturing firms patent (or not). NBER Working Paper, No. 7552.

Design Council. (2015). The design economy: the value of design to the UK. London: Design Council.

EUIPO (2018) IP litigation insurance landscape, April.

Fernandez-Ribas, A. (2010). International patent strategies of small and large firms: an empirical study of nanotechnology. Review of Policy Research, 27, 457-473.

Galasso, A., \& Schankerman, M. (2015). Patent rights and innovation by small and large firms. NBER working paper, 21769.

Galia, F., \& Zenou, E. (2012). Board composition and forms of innovation: does diversity make a difference? European Journal of International Management, 6, 630-650.

Gambardella, A., Giuri, P., \& Luzzi, A. (2007). The market for patents in Europe. Research Policy, 36, 1163-1183.

Giuri, P., Mariani, M., Brusoni, S., Crespi, G., Francoz, D., Gambardella, A., Garcia-Fontes, W., Geuna, A., Gonzales, R., Harhoff, D., Hoisl, K., Le Bas, C., Luzzi, A., Magazzini, L., Nesta, L., Nomaler, O., Palomerasi, N., Patel, P., Romanelli, M., \& Verspagen, B. (2007). Inventors and invention processes in Europe: Results from the PatVal-EU survey. Research Policy, 36, 1107-1127.

Griffith, R., Redding, S., \& Van Reenan, J. (2003). R\&D and absorptive capacity: theory and empirical evidence. Scandinavian Journal of Economics, 105, 99-118.

Gundry, L., Kickul, J., Welsch, H. P., \& Posig, M. (2003). Technological innovation in women-owned firms: influence of entrepreneurial motivation and strategic intention. The International Journal of Entrepreneurship and Innovation, 4, 265-274.

Hall, B. H., Helmers, C., Rogers, M., \& Sena, V. (2013). The importance (or not) of patents to UK firms. Oxford Economic Papers, 65(3), 603-629.

Hughes, A. and Mina, A. (2010) The impact of the patent system on SMEs. Cambridge Centre for Business Research.

IPO (2017) Building the Evidence Base on the Performance of the UK Patent System, UK Intellectual Property Office. Available at: https://assets.publishing.service.gov. uk/government/uploads/system/uploads/attachment data/file/639203/building-evidence-performance-patentsystem.pdf. accessed 31Jan 2020.

Kingston, W. (2001). Innovation needs patents reform. Research Policy, 30, 403-423. 
Kok, R. A. W., \& Ligthart, P. E. M. (2014). Differentiating major and incremental new product development: the effects of functional and numerical workforce flexibility. Journal of Product Innovation Management, 31, 30-42.

Kopel, M., \& Loffler, C. (2008). Commitment, first-mover-, and second-mover advantage. Journal of Economics, 94, 143166.

Leonard-Barton, D. (1992). Core capabilities and core rigidities: a paradox in managing new product development. Strategic Management Journal, 13, 111-125.

Levin, R.C., Klevorick, A.K., Nelson, R.,R., Winter, S.G., Gilbert, R., \& Z. Griliches (1987) Appropriating the Returns from Industrial Research and Development, Brookings Papers on Economic ActivityVol. 1987, No. 3, Special Issue On Microeconomics, pp. 783-831.

Marzi, G., Dabic, M., Daim, T., \& Garces, E. (2017). Product and process innovation in manufacturing firms: a 30-year bibliometric analysis. Scientometrics, 113, 673-704.

Mina, A., Bascavusoglu-Moreau, E., \& Hughes, A. (2014). Open service innovation and the firm's search for external knowledge. Research Policy, 43, 853-866.

Pajak, S. (2016). Do innovative firms rely on big secrets? An analysis of IP protection strategies with the CIS 4 survey. Economics of Innovation and New Technology, 25(5), 516532.

Perez-Cano, C., \& Villen-Altamirano, J. (2013). Factors that influence the propensity to patent. Emj-Engineering Management Journal, 25, 27-38.

Rosing, K., Frese, M., \& Bausch, A. (2011). Explaining the heterogeneity of the leadership-innovation relationship: ambidextrous leadership. Leadership Quarterly, 22, 956-974.

Scherer, F. M., \& Harhoff, D. (2000). Technology policy for a world of skew-distributed outcomes. Research Policy, 29(45), 559-566.

Schumpeter, J.A. 1912. Theorie der wirtschaftlichen Entwicklung Leipzig: Duncker \& Humblo.
Simon, H. (1996). Hidden champions - lessons from 500 of the world's best unknown companies. Boston: Harvard Business School Press.

Talke, K., Salomo, S., \& Rost, K. (2010). How top management team diversity affects innovativeness and performance via the strategic choice to focus on innovation fields. Research Policy, 39, 907-918.

Ulhoi, J. P. (2012). Modes and orders of market entry: revisiting innovation and imitation strategies. Technology Analysis \& Strategic Management, 24, 37-50.

Vahter, P., Love, J. H., \& Roper, S. (2014). Openness and innovation performance: are small firms different? Industry and Innovation, 21, 553-573.

Valentim, L., Lisboa, J. V., \& Franco, M. (2016). Knowledge management practices and absorptive capacity in small and medium-sized enterprises: is there really a linkage? $R \& D$ Management, 46, 711-725.

Veer, T., \& Jell, F. (2012). Contributing to markets for technology? A comparison of patent filing motives of individual inventors, small companies and universities. Technovation, 32, 513-522.

Venohr, B. and Mayer, K.E. (2007) The German miracle keeps running: how Gemany's hidden champions stay ahead in the global economy mimeo.

Vossen, R. W. (1998). Relative strengths and weaknesses of small firms in innovation. International Small Business Journal, $16,88-95$.

WIPO (undated) 'Managing patent costs: an overview'. Available at: https://www.wipo.int/export/sites/www/sme/ en/documents/pdf/managing_patent_costs.pdf. Accessed 30 Jan 2020

Publisher's note Springer Nature remains neutral with regard to jurisdictional claims in published maps and institutional affiliations. 